\title{
Effects of Food Processing on Resveratrol and Total Phenolic Content in Melinjo (Gnetum gnemon L.) Seeds
}

\author{
Islamudin Ahmad', Desta Andriyani ${ }^{2}$, Christoper Gunawan², Nisrina Dhiah Fauziah², Sutriyo Sutriyo ${ }^{3}$, \\ Abdul Mun'im ${ }^{2 *}$
}

\section{Islamudin Ahmad', Desta Andriyani ${ }^{2}$, Christoper Gunawan ${ }^{2}$, Nisrina Dhiah Fauziah $^{2}$, Sutriyo Sutriyo ${ }^{3}$, Abdul Mun'im ${ }^{2, *}$}

\section{'Laboratory of Pharmaceutical Research and Development of FARMAKA TROPIS, Faculty of Pharmacy, Mulawarman University, Samarinda, East Kalimantan, INDONESIA. ${ }^{2}$ Laboratory of Pharmacognosy- Phytochemistry, Faculty of Pharmacy, Universitas Indonesia, Depok, West Java, INDONESIA. \\ ${ }^{3}$ Laboratory of Pharmaceutics, Faculty of Pharmacy, Universitas Indonesia, Depok, West Java, INDONESIA. \\ Correspondence \\ Dr. Abdul Mun'im}

Laboratory of PharmacognosyPhytochemistry, Faculty of Pharmacy, Universitas Indonesia, Depok, West Java, INDONESIA.

Phone no : +62 85216104550

E-mail:munimabdoel@gmail.com

History

- Submission Date: 14-03-2018

- Review completed: 28-06-2018;

- Accepted Date: 18-07-2018

DOI : 10.5530/pj.2018.6.186

Article Available online

http://www.phcogj.com/v10/i6

Copyright

(C) 2018 Phcog.Net. This is an openaccess article distributed under the terms of the Creative Commons Attribution 4.0 International license.

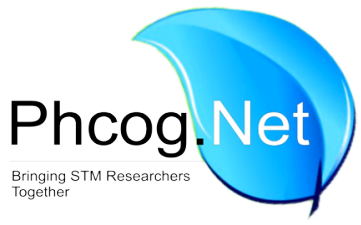

\begin{abstract}
Objective: Trans-resveratrol is a phenolic compound in the stilbene group present in Melinjo (Gnetum gnemon L.) seeds. In Indonesia, these seeds are consumed by roasting, frying (i.e., emping), and boiling. This study aimed to evaluate the effects of food processing on trans-resveratrol and total phenolic compound levels in melinjo seeds. Methods: Melinjo seed was roasted at $145^{\circ} \mathrm{C}$ for 10 and $20 \mathrm{~min}$, boiled at $100^{\circ} \mathrm{C}$ for 5,15 , and $30 \mathrm{~min}$, and fried at $160-170^{\circ} \mathrm{C}$ for 2 and 4 min. Samples were refluxed with $96 \%$ ethanol. The determination of trans-resveratrol levels was performed using high-performance liquid chromatography (HPLC), and total phenolic content was determined using Folin-Ciocalteu method. Results: Based on the results, it was found that trans-resveratrol and total phenolic content levels in Melinjo powder decreased from 36\% to $10 \%$ (trans-resveratrol) and $15 \%$ to $4 \%$ (total phenolic) after 20 min of roasting, and in fried empings, it decreased $60 \%, 68 \%$, and $92 \%$ (trans-resveratrol) and 41\%, 45\%, 97\% (total phenolic) after 5, 15, and 30 min of boiling, respectively. Conclusion: There were significant changes in trans-resveratrol levels and total phenolic content in Melinjo seeds before and after various cooking processes (i.e., roasting, boiling, and frying).
\end{abstract}

Key words: Food processing, Melinjo seeds, Gnetum gnemon L., Resveratrol levels, Total phenolic content.

\section{INTRODUCTION}

Melinjo (Gnetum gnemon L.) or in Sundanese is known as "Tangkil," is a species of Gnetum (Gymnospermae) native to tropic Asia, Melanesia, and West Pacific. Melinjo seeds have been consumed by the community as vegetables and as a snack in the form of Melinjo chips. The seed was reported to demonstrate some pharmacological activity, such as antioxidants, ${ }^{1}$ anticancer, ${ }^{2}$ anti-coagulant, ${ }^{3}$ hyperuricemia, ${ }^{4}$ HMG-CoA reductase, ${ }^{5-6}$ anti-obesity, ${ }^{7}$ an $\mathrm{d}$ angiotensin-converting enzyme inhibitory. ${ }^{8}$

The seeds are rich-in stilbenes, such as resveratrol, which occurs as two isomers: cis-resveratrol and trans-resveratrol. Both isomers have different biological activity (such as antioxidant, HMG-CoA reductase, antihypertension, and so on). However, effects produced by trans-resveratrol are stronger than the results produced by cis-resveratrol..$^{9-10}$ It has also been found that resveratrol stability is affected by light and high temperatures. ${ }^{11}$ In Indonesia culinary practices, Melinjo seeds are often as snack food ingredient and are processed into sundried, flat cakes called emping, which are fried in cooking oil before consumption. ${ }^{12}$ The seeds are also consumed as an additional ingredient in Indonesian soup (i.e., Sayur Asem) or boiled with vegetables and spices. As a foodstuff, Melinjo seeds have also been reported to have no toxic effects when consumed over long periods of time. ${ }^{13}$

Food processing that involves heat, including roasting, baking, boiling, and frying, affect chemical compounds in some plants and foodstuffs. Previous studies have shown that the roasting process alters structural and chemical compounds by decreasing liquid content, modifying lipids, and causing discoloration and flavor changes. ${ }^{14}$ Additionally, one study reported that trans-resveratrol level in roasted peanuts was less than in raw peanuts, ${ }^{15}$ while another study reported that trans-resveratrol levels in raw blueberries were higher than in roasted blueberries. ${ }^{16}$ However, research of food processing on the concentration of trans-resveratrol and total phenolic content in Melinjo seeds has not been reported. The current study was conducted to determine the food processing effect by roasting, boiling, and frying and its duration on Melinjo seeds on trans-resveratrol and phenolic content.

Cite this article: Ahmad I, Andriyani D, Gunawan C, Fauziah ND, Sutriyo S, Mun'im A. Effects of Food Processing on Resveratrol and Total Phenolic Content in Melinjo (Gnetum gnemon L.) Seeds. Pharmacog J. 2018;10(6):1096-100. 
Ahmad, et al.: Effects of Food Processing on Total Phenolic and Resveratrol in Melinjo seeds

\section{MATERIALS AND METHODS}

\section{Plant Material}

Melinjo (Gnetum gnemon L.) seeds were achieved from Pandeglang traditional market, Banten Province, Indonesia and authenticated at the Herbarium Bogoriense, Bogor, and West Java, Indonesia. The voucher specimen was deposited at Herbarium of Pharmacognosy-Phytochemistry, Faculty of Pharmacy, Universitas Indonesia, Depok, and West Java, Indonesia.

\section{Chemical Materials and General Equipment}

The chemicals were used in this study, such as ethanol, aqua DM, ethyl acetate, $\mathrm{n}$-hexane were purchased from PT. Smart Lab Indonesia, Indonesia. Acetonitrile, acetic acid, Folin-Ciocalteau reagent, sodium carbonate, methanol pro analysis were obtained from PT. Merck, Germany via PT Elo Karsa Utama, Indonesia. The equipment were used including oven vacuum (Jisico, Korea), rotary vacuum evaporator (Buchi, Switzerland), high-performance liquid chromatography (HPLC) (Shimadzu SPD-20A, Japan), and microplate reader (Versa Max, USA).

\section{Food Processing \\ Fried Emping}

Raw emping was fried in cooking oil for 2 and 4 min at $160-170^{\circ} \mathrm{C}$ and the oil removed by refluxing with $\mathrm{n}$-hexane. Both raw and the fried emping were ground into powder.

\section{Roasted Melinjo seed powder}

Melinjo seeds were peeled to remove the outer shell and to expose the yellowish white inner seed before being ground into powder with a blender. This powder was inserted into a drying cabinet equipped with lights for seven days; after which time, the powder was removed for use in the experiment. Melinjo seed powder with and without eggs was roasted in an oven at $145^{\circ} \mathrm{C}$ for 10 and $20 \mathrm{~min}$ and cooled to room temperature.

\section{Boiled Melinjo Seeds}

Melinjo seeds with and without skin were boiled in water at $100^{\circ} \mathrm{C}$ at a ratio of 1:5 (seeds: water) for 5, 15, and 30 min before removal and milling to powder.

\section{Extract Preparation}

All samples were refluxed ${ }^{17}$ using $96 \%$ ethanol (Merck, Germany) for $1 \mathrm{~h}$. The same procedure was repeated three times. The solvent was removed using a rotary vacuum evaporator at $50^{\circ} \mathrm{C}$, and the samples were dried using an oven vacuum at $50^{\circ} \mathrm{C}$.

\section{Determination of Resveratrol Content Using High- Performance Liquid Chromatography (HPLC)}

Trans-resveratrol levels were determined using HPLC according to the Suoto method. ${ }^{18}$ with modification. Reverse phase HPLC was performed using a C18 column ( $5 \mu \mathrm{m}$ particle size, $4.6 \times 150 \mathrm{~mm}$, Zorbax). The mobile phase was conducted in acetonitrile: water (25:75) solution (Merck, Germany), with the $\mathrm{pH}$ adjusted to 3 using acetic acid. Ultraviolet detection was performed at $306 \mathrm{~nm}$, the flow rate was determined to be $1 \mathrm{ml} / \mathrm{min}$, and the injection volume was determined to be $20 \mu \mathrm{l}$.

\section{Determination of Total Phenolic Content (TPC)}

TPC was determined using the Folin-Ciocalteau (F-C) method. Each sample weighed 20 grams and was dissolved in a methanol aqua demineralization mixture diluted to $400 \mathrm{ppm} ; 20 \mu \mathrm{L}$ of the solution was pipetted and inserted into a 96-well microplate with each sample done in triplicate. Then, $100 \mu \mathrm{L}$ of an F-C reagent was added, and the mixture was shaken for $1 \mathrm{~min}$ and incubated for $4 \mathrm{~min}$. Then, $75 \mu \mathrm{L}$ of $\mathrm{Na}_{2} \mathrm{CO}_{3}$ solution was shaken for $1 \mathrm{~min}$ and incubated for $120 \mathrm{~min}$. After the incubation process, the absorbance of the solution was measured using a microplate reader. ${ }^{19-21}$

\section{RESULTS AND DISCUSSION}

In present study, the influence of food processes (including roasting, boiling, and frying) on the difference of trans-resveratrol and polyphenolic content of Melinjo seeds has been done. After the food processes, then each sample was macerated using $96 \%$ ethanol. The obtained extract was analyzed trans-resveratrol levels and total polyphenolics content.

\section{Determination of Resveratrol Content}

As can be seen in Figure 1, resveratrol level was calculated using a calibration curve and the regression equation $y=167959 x+2341.5$ with $\mathrm{R}$ value $=0.9991$. Retention time was used to identify trans-resveratrol in a sample. The peak of the trans-resveratrol standard is shown at an 8 -min retention time.

Table 1 shows an increasing level of trans-resveratrol in Melinjo seed powder without egg (36\%) compared to powder with egg (12\%) after roasting for $10 \mathrm{~min}$. This result was similar to previous research conducted by Rudolf (2003), ${ }^{22}$ which showed that trans-resveratrol levels in nuts increased after the roasting and has been patented since $2010 .^{23}$ Trans-resveratrol content decreased by $10 \%$ in the sample without eggs and by $24 \%$ in the sample with eggs after baking for $20 \mathrm{~min}$, possibly due to stilbene compounds, particularly resveratrol, being damaged..$^{15}$ Protein in eggs is known to easily denature at high temperatures, with the denaturation product forming aggregates, including ovalbumin. ${ }^{24}$ These protein aggregates are water insoluble; thus, high temperatures decrease protein solubility. ${ }^{25}$

The trans-resveratrol level of fried emping is shown in Table 2 and was found to decrease after the frying process, which is similar to previous results for Vaccinium myrtillus L. and Vaccinium corymbosum L. after baking. ${ }^{16}$ Another study reported that trans-resveratrol level in raw peanuts was higher than in roasted peanut, ${ }^{26}$ including grapes, and may be one of the compounds responsible for the health benefits of red wine. Analytical methods for measuring resveratrol in wine and peanuts were adapted to isolate, identify, and quantify resveratrol in several cultivars of peanuts. Aqueous ethanol $(80 \% \mathrm{v} / \mathrm{v}$ Trans-resveratrol content in boiled melinjo (Table 1) decreased over time because of the instability of resveratrol. This instability was investigated by Zupancic et al. ${ }^{27}$ this paper presents newly determined trans-RSV solubility and stability at various $\mathrm{pH}$ and temperatures, and the importance of such data for the studies of novel trans-RSV-loaded nanofibers. In acidic $\mathrm{pH}$ trans-RSV was stable, whereas its degradation started to increase exponentially above $\mathrm{pH} 6.8$. Consequently, it is worthwhile to note that special consideration has to be dedicated to long dissolution testing or biological assays on cell lines in order to obtain relevant data. Measurements were done by validated

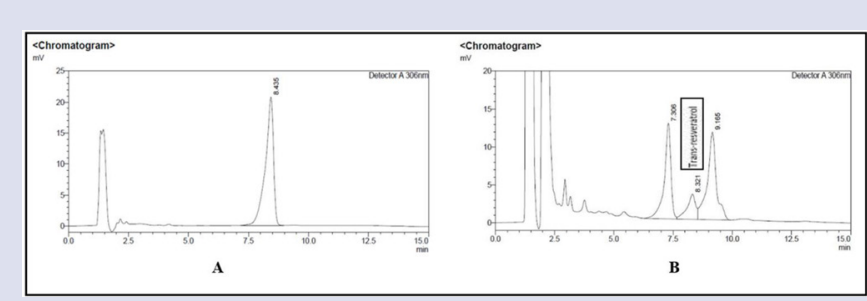

Figure 1: (A) Chromatogram of standard trans-resveratorl; (B) Chromatogram of sample. 
Table 1: Resveratrol content in melinjo powder, emping, and melinjo seeds.

\begin{tabular}{cccc}
\hline Sample & Min & $\begin{array}{c}\text { Resveratrol Content } \\
(\mathrm{mg} / \mathrm{g})\end{array}$ & Changes (\%) \\
\hline Melinjo powder & 0 & $0.1025 \pm 0.0075$ & \\
without egg & 10 & $0.1397 \pm 0.0076^{*}$ & 36,00 \\
Melinjo powder & 20 & $0.1262 \pm 0.0090^{*}$ & 10,00 \\
with egg & 0 & $0.0870 \pm 0.0104$ & \\
& 10 & $0.0973 \pm 0.0147$ & 12,00 \\
Raw emping & 20 & $0.0738 \pm 0.0076^{*}$ & 24,00 \\
Fried emping & 2 & $0.123 \pm 0.002$ & \\
Fried emping & 4 & $0.095 \pm 0.002^{*}$ & 22.76 \\
Melinjo seeds & 0 & $0.085 \pm 0.002^{*}$ & 30.89 \\
without skin, boiled & 5 & 1.028 & \\
& 15 & 0.375 & 63.81 \\
& 30 & 0.113 & 68.42 \\
Melinjo seeds with & 0 & 0.008 & 91.67 \\
skin, boiled & 5 & 1.259 & 66.4 \\
& 15 & 0.412 & 64.29 \\
& 30 & 0.140 & 93.33 \\
\hline
\end{tabular}

* Significant change.

Table 2: Total Polyphenolics Content in melinjo powder, emping, and melinjo seeds.

\begin{tabular}{cccc}
\hline Sample & Min & $\begin{array}{c}\text { Total Phenolic Content } \\
\text { (mg GAE/g) }\end{array}$ & Changes (\%) \\
\hline Melinjo powder & 0 & $10.6436 \pm 0.2444$ & \\
without egg & 10 & $12.2379 \pm 0.3543^{*}$ & 15.00 \\
& 20 & $11.6923 \pm 0.6070^{*}$ & 4.00 \\
Melinjo powder & 0 & $7.2126 \pm 0.4675$ & \\
with egg & 10 & $7.2482 \pm 0.3052^{*}$ & 0.50 \\
Raw emping & 0 & $6.2451 \pm 0.2226^{*}$ & 14.00 \\
Fried emping & 2 & $99.621 \pm 0.63$ & \\
Fried emping & 4 & $84.829 \pm 1.013^{*}$ & 14.85 \\
Melinjo seeds & 0 & $56.794 \pm 1.14^{*}$ & 42.99 \\
without skin, & 5 & 45.312 & \\
boiled & 15 & 26.629 & 40.79 \\
& 30 & 14.799 & 44.76 \\
Melinjo seeds & 0 & 0.421 & 97.17 \\
with skin, & 5 & 48.456 & 36.43 \\
boiled & 15 & 29.425 & 97.34 \\
& 30 & 18.758 & \\
\hline
\end{tabular}

* Significant change

UV/VIS spectroscopy, HPLC, and newly developed UPLC methods. Specificity was confirmed for HPLC and UPLC method, whereas UV/ VIS spectroscopy resulted in false higher trans-RSV concentrations in conditions under which it was not stable (alkaline $\mathrm{pH}$, light, increased temperature who found that trans-resveratrol stability was dependent on temperature; when trans-resveratrol was heated to over $30^{\circ} \mathrm{C}$, its isomerization form changed from trans-resveratrol to cis-resveratrol.
Additionally, as the temperature increased trans-resveratrol degraded into a degradation product. To test the results, the data were analyzed using statistical package for the social sciences (SPSS) using a one-way analysis of variance (ANOVA) method, which indicated that changes in trans-resveratrol level were significant $(p<0.05)$.

\section{Determination of Total Phenolic Content (TPC)}

As can be seen in Table 2, demonstrated TPC in roasted Melinjo seed powder, including changes when eggs were included $(p<0.05)$. These results supported the results obtained using HPLC. Xu and Chang (2008) found that temperature treatments, such as heating or roasting, of plants likely evaporated water at an intracellular level, triggering chemical reactions resulting in cell structure changes and increasing the availability of phenolic compounds in plant matrices. ${ }^{28}$ Similarly, Yang et al. reported that the TPC of beans roasted for $5 \mathrm{~min}$ increased compared to raw beans. ${ }^{29}$ and Hečimović et al. also reported the comparative study of polyphenols and caffeine in different coffee varieties affected by the degree of roasting. ${ }^{30}$ The change in TPC in fried emping was also significant $(p<0.05)$, based on a one-way ANOVA and Tukey's post hoc analysis. A decrease was expected because the polyphenol group is heat sensitive, which includes resveratrol. Previous studies reported that the TPC in Melinjo seeds decreased during the boiling process, ${ }^{1}$ which was supported in the presents study; the TPC in boiled Melinjo seeds decreased with boiling time (Table $2 ; p<0.05$ ). This decrease occurred because the heating process in boiling made polyphenolic molecules unstable and ruptured molecule bonds.

\section{CONCLUSION}

Based on the results above, Effects of food processing on concentration of trans-resveratrol and total phenolic content in Melinjo (Gnetum gnemon L.) seeds has been performed. There were significant changes in trans-resveratrol levels and total phenolic content in Melinjo seeds before and after various cooking processes (i.e., roasting, boiling, and frying). The difference of trans-resveratrol and phenolic content in each food processing of Melinjo seeds is preliminary data for further study and its effect on pharmacological effects.

\section{ACKNOWLEDGEMENT}

The authors wish to acknowledge support from the PITTA 2017 grant issued by the Directorate of Research and Community Engagement (DRPM), Universitas Indonesia.

\section{CONFLICT OF INTEREST}

All author declared that have no conflict of interest.

\section{ABBREVIATIONS}

HMG-CoA: 3-hydroxy-3-methylglutaryl coenzyme A; HPLC: Highperformance liquid chromatography; TPC: Total phenolic content; F-C: Folin-Ciocalteau; SPSS: Statistical package for the social sciences; ANOVA: Analysis of variance; PITTA: Publikasi Internasional Terindeks untuk Tugas Akhir Mahasiswa; DRPM: Direktorat Riset dan Pengabdian kepada Masyarakat.

\section{REFERENCES}

1. Santoso M, Naka Y, Angkawidjaja C, Yamaguchi T, Matoba T, Takamura $H$. Antioxidant and DNA damage prevention activities of the edible parts of Gnetum gnemon and their changes upon heat treatment. Food SciTechnol Res. 2010;16(6):549-56. doi:10.3136/fstr.16.549

2. Narayanan NK, Kunimasa K, Yamori $Y$, et al. Antitumor activity of melinjo (Gnetum gnemon L.) seed extract in human and murine tumor models in vitro and in acolon-26 tumor-bearing mouse model in vivo. Cancer Med. 2015;4(11):1767-80. doi:10.1002/cam4.520. 
3. ChibaT, KimuraY, Suzuki S, Tatefuji T, Umegaki K. Trans-resveratrol enhances the anticoagulant activity of warfarin. J Atheroscler Thromb. 2016;23(9):1099-110. doi:10.5551/jat.31765

4. Saifudin A, Suryadini H, Sujono TA, Suhendi A, Tanaka K, Tezuka Y. Serum uric acid concentration due to Gnetum gnemon chip supplementation and quality changes analyses based on its chemical constituents in post-frying process. $J$ Food Process Preserv. 2017;1-6. doi:10.1111/jfpp.13535.

5. Hafidz KA Puspitasari N Yanuar AA Artha Y Mun'im A. HMG-CoA reductase inhibitory activity of Gnetum gnemon seed extract and identification of potential inhibitors for lowering cholesterol level. J Young Pharm. 2017;9(4):559-65. doi:10.5530/jyp.2017.

6. Elfiyani R, Amalia A, Pratama SY. Effect of using the combination of tween 80 and ethanol on the forming and physical stability of microemulsion of Eucalyptus Oil as Antibacterial. J Young Pharm. 2017;9(3):S1-S4. doi:10.5530/jyp.2017.

7. Ikuta T, Saito S, Tani H, Tatefuji T, Hashimoto K. Resveratrol derivative-rich melinjo (Gnetum gnemon L.) seed extract improves obesity and survival of C57BL/6 mice fed a high-fat diet. Biosci Biotechnol Biochem. 2015;79(12):2044-9. doi:10 $.1080 / 09168451.2015 .1056510$

8. Mun'im A, Munadhil MA, Puspitasari N, Yanuar AA. Angiotensin converting enzyme inhibitory activity of Melinjo (Gnetum gnemon L.) seed extracts and molecular docking of its stilbene constituents. Asian J Pharm Clin Res. 2017:10(3):1-6. doi:10.22159/ajpcr.2017.v10i3.16108.

9. Likhtenshtein G. Stilbenes: Applications in Chemistry, Life Sciences and Materials Science. New York Dordrecht Heidelberg London Library: WILEY-VCH Verlag GmbH and Co. KGaA, Weinheim. 2010.

10. Donglikar MM, Deore SL. Development and evaluation of herbal sunscreen. Pharmacogn J. 2017;9(1):83-97.

11. Guamán-Balcázar MC, Setyaningsih W, Palma M, Barroso CG. Ultrasoundassisted extraction of resveratrol from functional foods: Cookies and jams. Appl Acoust. 2016;103:207-13. doi:10.1016/j.apacoust.2015.07.008.

12. Barua C, Haloi P, Barua I. Gnetum gnemon linn. : A comprehensive review on its biological, pharmacological and pharmacognostic potentials. Int J Pharmacogn Phytochem Res. 2015;7(3):531-9.

13. Tatefuji T, Yanagihara M, Fukushima $S$, Hashimoto K. Safety assessment of melinjo (Gnetum gnemon L.) seed extract: Acute and subchronic toxicity studies. Food Chem Toxicol. 2014;67:230-5. doi:10.1016/j.fct.2014.02.030.

14. Chang SK, Alasalvar C, Bolling BW, Shahidi F. Nuts and their co-products: The impact of processing (roasting) on phenolics, bioavailability, and health benefits - A comprehensive review. J Funct Foods. 2016;26:88-122. doi:10.1016/j.jff.2016.06.029.

15. Lee SS, Lee SM, Kim M, Chun J, Cheong YK, Lee J. Analysis of trans-resveratrol in peanuts and peanut butters consumed in Korea. Food Res Int. 2004;37(3):247-51. doi:10.1016/j.foodres.2003.11.007.

16. Lyons MM, Yu C, Toma RB, et al. Resveratrol in raw and baked blueberries and bilberries. J Agric Food Chem. 2003;51(20):5867-70. doi:10.1021/jf034150f.
17. Ahmad I, Ambarwati NSS, Indriyanti N, Sastyarina Y, Rijai L, Mun'im A. Oral glucose tolerance activity of Bawang Dayak (Eleutherine palmifolia L. Merr.) bulbs extract based on the use of different extraction method. Pharmacogn J. 2018;10(1). doi:10.5530/pj.2018.1.10.

18. Souto AA, Carneiro MC, Seferin M, Senna MJH, Conz A, Gobbi K. Determination of trans-resveratrol concentrations in Brazilian red wines by HPLC. J Food Compos Anal. 2001;14(4):441-5. doi:10.1006/jfca.2000.0970.

19. Ahmad I, Yanuar A, Mulia K, Mun'im A. Application of ionic liquid as a green solvent for polyphenolics content extraction of Peperomia pellucida (L) Kunth herb. J Young Pharm. 2017;9(4):486-90. doi:10.5530/jyp.2017.

20. Ahmad I, Yanuar A, Mulia K, Mun'im A. Optimization of ionic liquid-based microwave-assisted extraction of polyphenolic content from Peperomia pellucida (L) kunth using response surface methodology. Asian Pac J Trop Biomed. 2017;7(7):660-5. doi:10.1016/j.apjtb.2017.06.010

21. Bobo-García G, Davidov-Pardo G, Arroqui C, Vírseda P, Marín-Arroyo M, Navarro M. Intra-laboratory validation of microplate methods for total phenolic content and antioxidant activity on polyphenolic extracts, and comparison with conventional spectrophotometric methods. J Sci Food Agric. 2014;95(1):204-9. doi:10.1002/ jsfa.6706.

22. Rudolf JL. Development of an HPLC method for resveratrol and optimization of post-harvest stress to induce production in peanuts. 2003

23. Resurreccion AVA, Rudolf JL, Phillips RD, Chinnan M. Method for enhancing resveratrol content of peanut compositions. United State Patent; 2010: Patent no.: US 7,666,455 B2.

24. Deleu LJ, Wilderjans E, Van Haesendonck I, Brijs K, Delcour JA. Protein network formation during pound cake making: The role of egg white proteins and whea flour gliadins. Food Hydrocoll. 2016;61:409-14. doi:10.1016/j.foodhyd.2016.05.001.

25. Nasabi M, Labbafi M, Mousavi ME, Madadlou A. Effect of salts and nonionic surfactants on thermal characteristics of egg white proteins. Int J Biol Macromol. 2017;102:970-6. doi:10.1016/j.ijbiomac.2017.04.102

26. Sanders TH, McMichael RW, Hendrix KW. Occurrence of resveratrol in edible peanuts. J Agric Food Chem. 2000;48(4):1243-6. doi:10.1021/jf990737b.

27. Zupancic Š, Lavric Z, Kristl J. Stability and solubility of trans-resveratrol are strongly influenced by $\mathrm{pH}$ and temperature. Eur J Pharm Biopharm. 2015;93:196-204. doi:10.1016/j.ejpb.2015.04.002

28. Xu B, Chang SKC. Total phenolics, phenolic acids, isoflavones, and anthocyanins and antioxidant properties of yellow and black soybeans as affected by therma processing. J Agric Food Chem. 2008;56(16):7165-75. doi:10.1021/jf8012234

29. Yang HW, Hsu CK, Yang YF. Effect of thermal treatments on anti-nutritional factors and antioxidant capabilities in yellow soybeans and green-cotyledon small black soybeans. J Sci Food Agric. 2014;94(9):1794-801. doi:10.1002/jsfa.6494.

30. Hecimovic I, Belšcak-Cvitanovic A, Horžic D, Komes D. Comparative study of polyphenols and caffeine in different coffee varieties affected by the degree of roasting. Food Chem. 2011;129(3):991-1000. doi:10.1016/..foodchem.2011.05.059.

\section{GRAPHICAL ABSTRACT}

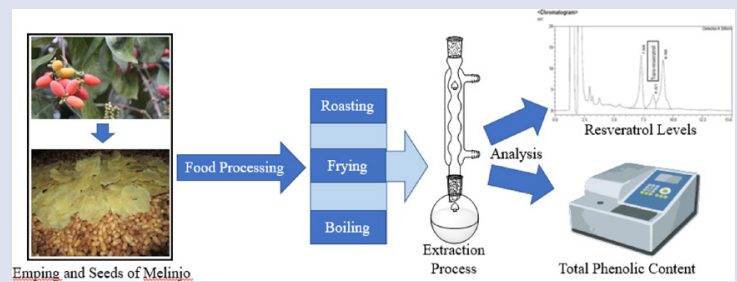

\section{SUMMARY}

- Trans-resveratrol is a phenolic compound in the stilbene group present in Melinjo (Gnetum gnemon L.) seeds.

- Trans-resveratrol and total phenolic content levels in Melinjo powder decreased from $36 \%$ to $10 \%$ (resveratrol) and $15 \%$ to $4 \%$ (total phenolic) after $20 \mathrm{~min}$ of roasting.

- Trans-resveratrol and total phenolic content levels in fried empings decreased was $60 \%, 68 \%$, and $92 \%$ (trans-resveratrol) and $41 \%, 45 \%, 97 \%$ (total phenolic) after 5,15 , and 30 min of boiling.

- The significant changes in trans-resveratrol levels and total phenolic content in Melinjo seeds before and after various cooking processes.

\section{ABOUT AUTHORS}

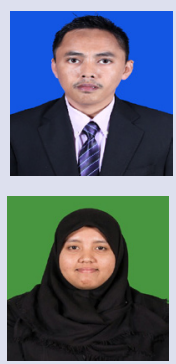

Dr. Islamudin Ahmad, a lecturer at Department of Pharmaceutical Sciences, Faculty of Pharmacy, Mulawarman University, Samarinda, East Kalimantan, Indonesia. He has experience in the area of Pharmacognosy and Natural Product Chemistry, working in drugs discovery of natural products, extraction engineering, isolation and identification of active compound, screening activity mainly degenerative diseases.

Desta Andriyani, a Bachelor of Pharmacy and student of Profesi Apoteker at Faculty of Pharmacy, Universitas Indonesia, Depok. 


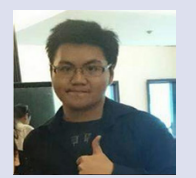

Christoper Gunawan, a Bachelor of Pharmacy and student of Profesi Apoteker at Faculty of Pharmacy, Universitas Indonesia, Depok.

Nisrina Dhiah Fauziah, a Bachelor of Pharmacy and student of Profesi Apoteker at Faculty of Pharmacy, Universitas Indonesia, Depok.

Dr. Sutriyo, associate professor at Department of Pharmaceutical Sciences, Faculty of Pharmacy, Universitas Indonesia, Depok, West Java, Indonesia. He has experience in the area of Pharmaceutic and Pharmaceutical Technology.

Dr. Abdul Mun'im, associate professor at Department of Pharmaceutical Sciences, Faculty of Pharmacy, Universitas Indonesia, Depok, West Java, Indonesia. He has experience in the area of pharmacognosy and phytochemistry, working in drugs discovery of herbal plants, extraction engineering, metabolite profiling, structure elucidation, and degenerative diseases (such as diabetes mellitus, antihypertension, and cholesterol).

Cite this article: Ahmad I, Andriyani D, Gunawan C, Fauziah ND, Sutriyo S, Mun'im A. Effects of Food Processing on Resveratrol and Total Phenolic Content in Melinjo (Gnetum gnemon L.) Seeds. Pharmacog J. 2018;10(6):1096-100. 